\title{
THE LANGUAGE OF ADMINISTRATIVE LAW
}

\author{
Paul Daly*
}

Administrative law has changed radically in its scope and breadth in recent decades. Old analytical frameworks have been cast aside and replaced by more open-textured concepts, such as "legality", "rationality" and "fairness." In demonstrating that administrative decisions are beyond the legal pale, lawyers have resort to various devices: mission statements, labels, terminological exactitude, metaphors and personification.

Although language plays a useful descriptive role in administrative law, by setting out a landscape that can be comfortably viewed and usefully discussed from 20,000 feet, overreliance on these devices obfuscates the inevitably normative task judges have in judicial review cases: deciding and explaining whether intervention would be justifiable or not. Falling back on language may be a coping mechanism for judges, lawyers and academics deprived by the recent administrative law reformations of clear principles around which their work can be organized.

In this paper, I demonstrate the limits of language in administrative law, with a view to understanding the role of judicial review more clearly. Descriptive language is often either useless-because it adds nothing but a conclusory label to a conclusion reached on other grounds-or downright dangerous-because it hides judicial value judgments.

Administrative lawyers have to think and judges to justify themselves in normative terms. Mission statements, labels, terminological exactitude, metaphors and personification are descriptive devices better left to others.

La portée et l'étendue du droit administratif ont radicalement changé au fil des dernières décennies. Les anciens cadres analytiques ont été mis au rebut et remplacés par des concepts plus ouverts tels que ceux de "légalité », "rationalité 》 et "équité 》. Pour établir que les décisions administratives excèdent les limites de la légalité, les juristes disposent d'un arsenal varié : énoncés de mission, étiquetage, exactitude terminologique, métaphores et personnification.

Bien que le langage joue un rôle descriptif utile en droit administratif, en établissant un contexte pouvant aisément être examiné et discuté de loin, une dépendance excessive en ce moyen complique la tâche inévitablement normative qui échoit aux juges chargés du contrôle judiciaire : décider et

* Senior Lecturer in Public Law, University of Cambridge and Derek Bowett Fellow in Law, Queens' College, Cambridge. 
expliquer le bien-fondé de la décision d'intervenir ou de ne pas intervenir. Le fait de se replier sur le libellé peut être un mécanisme d'adaptation auquel ont recours les juges, juristes et universitaires faute de principes clairs pouvant servir de points de repère pour organiser le travail à la suite de la récente réforme en droit administratif.

Dans cet article, je démontre les limites de l'analyse linguistique en droit administratif afin de mieux comprendre le rôle du contrôle judiciaire. Souvent, un libellé descriptif est soit inutile, car il n'ajoute rien qu'un élément de conclusion à laquelle le tribunal était déjà parvenu pour d'autres motifs, soit carrément dangereux, car il occulte les jugements de valeur judiciaires.

One writer has mischievously suggested that appellate law is a "language game" played by lawyers and judges. ${ }^{1}$ Judicial review of administrative action, which proceeds by way of pleadings based on a settled, silent record, is a form of appellate law. And it has a strong claim to be considered a "language game". For in administrative law, lawyers strive to portray decisions as "unreasonable" or "unfair", terms they explain by invoking the various devices I discuss in this paper: developing mission statements, labelling categories of decision, perfecting terminological exactitude, evoking spectrums of procedural protection and inventing hypothetical reasonable persons. From time to time, scholars have even relied on metaphor to explain the grand sweeps of administrative law: from a long "sleep", 2 to "twilight", 3 to "reformation", 4 to doctrinal ebbs and flows. ${ }^{5}$

In one way, this may simply be evidence of administrative law's existential "crisis", 6 provoked by "a dramatic and indeed radical change in the scope of judicial review". ${ }^{7}$ To appreciate the fascination of administrative

1 AW Brian Simpson, Reflections on the Concept of Law (Oxford: Oxford University Press, 2011) at 100.

2 Robert Stevens, The English Judges: Their Role in the Changing Constitution (Portland, OR: Hart Publishing, 2005) at 19.

3 HRW Wade, "The Twilight of Natural Justice" (1951) 67 LQR 103.

4 Richard Stewart, "The Reformation of American Administrative Law" (1975) 88 HLR 1667; Thomas Poole, "The Reformation of English Administrative Law" (2009) 68:1 CLJ 142 [Poole].

5 Claire L'Heureux-Dubé, “The 'Ebb' and 'Flow' of Administrative Law on the 'General Question of Law'" in Michael Taggart, ed, The Province of Administrative Law Determined (Oxford: Hart publishing, 1997) 308.

6 Martin Loughlin, "Procedural Fairness: A Study of the Crisis in Administrative Law Theory" (1978) 28 UTLJ 215.

$7 \quad$ Council of Civil Service Unions v Minister for Civil Service, [1985] AC 374 at 414, per Lord Roskill [Council of Civil Service]. 
lawyers with language, some background is necessary. Judicial review of administrative action began to emerge as a distinct branch of the law only in the mid-20th century. Administrative law, as it is typically called, has since blossomed as a result of judicial creativity. In the early-20th century, administrative action could be reviewed only in a narrow set of cases, where officials exercising statutory authority had determined, by a judicial process, the rights of an individual. ${ }^{8}$ Yet by the 1980 s, it was safe to say that any governmental decision affecting the rights, interests, property, privileges, or liberties of any person was reviewable by the courts to ensure the legality and rationality of the decision and the fairness of the decisionmaking process. ${ }^{9}$

Since then, doctrine has developed still further. For example, factual findings of officials may be reviewed; ${ }^{10}$ officials can be bound to promises made by them to individuals; ${ }^{11}$ and in many situations, individuals are entitled to reasons for adverse decisions. ${ }^{12}$ Such intrusive judicial review of official decision-making would have been unthinkable several decades ago. ${ }^{13}$ Administrative law's scope and depth have increased: these increasingly intrusive grounds of review are available against a wide variety of public and private actors performing governmental functions. Now, the tentacles of administrative law embrace not only officials acting under express statutory authorization but, sometimes, private bodies performing public functions. ${ }^{14}$ However, although there has been vibrant scholarly debate about the legitimacy of developing judicially imposed controls on official action, ${ }^{15}$ the origins and raison d'être of the administrative law revolution are obscure.

Three decades ago, Lord Diplock explained: “[T]he English law relating to judicial control of administrative action has been developed upon a case to case basis which has virtually transformed it over the last three decades". ${ }^{16}$

$8 \quad R v$ Electricity Commissioners, ex parte London Electricity Joint Committee Co (1920) Ltd, [1924] $1 \mathrm{~KB} 171$ at 204-205, per Atkin LJ; $R v$ Legislative Committee of the Church Assembly, ex parte Haynes-Smith, [1928] 1 KB 411 at 415, per Hewart CJ.

9 Lord Woolf of Barnes, "Droit Public_English Style" [1995] Pub L 57.

10 Ev Secretary of State for the Home Department, [2004] QB 1044.

$11 R v$ North and East Devon Health Authority, ex parte Coughlan, [2001] QB 213 [ex parte Coughlan].

12 Baker v Canada (Minister of Citizenship and Immigration), [1999] 2 SCR 817 [Baker].

13 Poole, supra note 4.

14 Dawn Oliver, Common Values and the Public-Private Divide (London: Butterworths, 1999).

15 See generally Christopher Forsyth, ed, Judicial Review and the Constitution (Oxford: Hart Publishing, 2000) [Forsyth].

16 Council of Civil Service, supra note 7 at 407. 
Another 30 years on, administrative lawyers continue to struggle to account for the transformation in principled terms. ${ }^{17}$ Falling back on language may be a coping mechanism for judges, lawyers and academics deprived of clear principles around which their work can be organized.

In general, language plays a useful descriptive role in administrative law, setting out a landscape that can be comfortably viewed and usefully discussed from 20,000 feet. However, overreliance on mission statements, labels, terminological exactitude, metaphor and personification obfuscates the inevitably normative task judges have in judicial review cases: deciding and explaining whether intervention would be justifiable or not. As Cooke $\mathrm{P}$ (as he then was) explained in Thames Valley Electric Power Board $v$ NZFP Pulp \& Paper Ltd:

$[\mathrm{N}]$ ever has it been suggested that the mere personal opinion of a Judge that a decision is unfair will justify holding it invalid. Nor is that ever likely to be suggested. The functions of exercising administrative discretion and judicially reviewing its exercise are fundamentally different. The line is not always easy to draw, but it has to be drawn. ${ }^{18}$

My goal here is to demonstrate the limits of language in administrative law, with a view to understanding the role of judicial review more clearly. Exposing the limits of the administrative law language game is not a frivolous endeavour:

\begin{abstract}
A man may take to drink because he feels himself to be a failure, and then fail all the more completely because he drinks. It is rather the same thing that is happening to the English language. It becomes ugly and inaccurate because our thoughts are foolish, but the slovenliness of our language makes it easier for us to have foolish thoughts. 19
\end{abstract}

My argument is not that administrative law doctrine can be made so clear as to become self-applying. Regardless of the rules or standards adopted judicial judgement will be necessary in applying them to individual cases. The point, rather, is that jurists who appreciate the limits of language in administrative law will think more clearly about doctrine and reach more accurate decisions. As one wise judge admonished: "care needs to be taken

17 See e.g. Jack Watson, "Clarity and Ambiguity: A New Approach to the Test of Legitimacy in the Law of Legitimate Expectations" (2010) 30:4 Legal Stud 633.

18 Thames Valley Electric Power Board v NZFP Pulp \& Paper Ltd, [1994] 2 NZLR 641 at 653.

19 George Orwell, Politics and the English Language, 1946, online: <http://www. orwell.ru/library/essays/politics/english/e_polit>. 
to distinguish analytical tools from conclusions which encapsulate value judgments but do not give any indication of the route to those conclusions". ${ }^{20}$

In setting out my argument, I refer in particular to three sets of reasons written or co-written by Justice Louis LeBel during his tenure on the Supreme Court of Canada in my analysis of the limits of language in contemporary administrative law. His careful concurring reasons in Toronto (City) v CUPE, Local 7921 laid bare many of the problems with Canadian administrative law by exposing the shallowness of judicial resort to terminological exactitude to explain substantive review cases, a problem to which he returned in his seminal joint majority reasons (with Justice Bastarache) in Dunsmuir v New Brunswick, 22 which set out the Canadian framework for substantive judicial review. Yet his opinion for the Court in Imperial Oil Ltd. $v$ Quebec (Minister of the Environment) ${ }^{23}$ bears testament to his belief in the power of the metaphor of a spectrum of governmental functions to elucidate the principles of procedural fairness.

\section{Mission Statements}

Perhaps the most attractive - though also the most facile - endeavour for those who think deeply about administrative law is to formulate a general principle that unifies disparate strands of case-law. This then functions as a mission statement, an administrative law raison d'être supposedly capable of guiding judges in the resolution of judicial review cases. ${ }^{24}$ In reality, though mission statements may provide a high-level overview of the task

$20 \quad R$ (Bibi) v Newham London Borough Council, [2001] EWCA Civ 607 at para 18 (per Schiemann LJ).

212003 SCC 63, [2003] 3 SCR 77 [CUPE (2003)]. I call it CUPE (2003) to distinguish it from C.U.P.E. v N.B. Liquor Corporation, [1979] 2 SCR 227, which is generally referred to as "CUPE". I must confess that I do not understand why one is supposed to refer to this foundational decision on deference as CUPE and not as New Brunswick Liquor. When a large institutional litigant is involved, it makes much more sense to employ the name of the smaller party as shorthand. Although I cannot claim to have researched the point minutely, it seems to me to be safe to say that the New Brunswick Liquor Corporation has not featured as often as the Canadian Union of Public Employees in important administrative law cases.

222008 SCC 9, [2008] 1 SCR 190 [Dunsmuir].

232003 SCC 58, [2003] 2 SCR 624 [Imperial Oil].

24 Though his comments relate to mission statements adopted by administrative decision-makers, Keane CJ's observations in Keogh v Criminal Assets Bureau, [2004] 2 IR 159 at 175 are worth quoting at length:

It is undoubtedly the case that documents such as the [Taxpayer's] Charter of Rights under consideration in the present case, whether so described or called a 'mission statement' or given some other title, frequently contain what are no more than praiseworthy statements of an aspirational nature designed to encourage the members of the organisation concerned to meet acceptable standards of behaviour in their dealings with the public and to give the latter some form of assurance that 
of judicial review, they provide little in the way of concrete guidance. ${ }^{25}$ Although they are "sometimes applied as if they were labels, somehow determining the outcome of a particular matter", rather, "they have to be seen for what they are, in their particular context". ${ }^{26}$

A particularly popular mission statement involves "abuse of power"; 27 that through judicial review judges seek to prevent public officers from abusing their powers. Unfortunately, the abuse of power mission statement "goes no distance to tell you, case by case, what is lawful and what is not"; rather, "[l] egal principle lies between the overarching rubric of abuse of power and the concrete imperatives of a rule-book". ${ }^{28}$ Much the same response can be given to the so-called "ultra vires" doctrine, which encapsulates the idea that in judicial review of administrative action courts do no more than enforce the formal boundaries established by legislation, ${ }^{29}$ but which has been exploded by the growing acceptance that judges have long looked to sources other than duly enacted laws to impose limits on executive action. ${ }^{30}$

Lord Diplock's tripartite classification of judicial review is another popular mission statement for administrative lawyers. In the $G C H Q$ case, he suggested that "one can conveniently classify under three heads the grounds upon which administrative action is subject to control by judicial review": illegality, irrationality and procedural impropriety. ${ }^{31}$ One finds echoes of this mission statement in a recent Canadian case: "Judicial review

complaints as to discourtesy or other shortcomings on the part of the former will be seriously entertained.

25 See generally Matthew Nathan Groves, "The Surrogacy Principle and Motherhood Statements in Administrative Law" in Linda Pearson, Carol Harlow \& Michael Taggart, eds, Administrative Law in a Changing State: Essays in Honour of Mark Aronson (Oxford, UK: Hart Publishing, 2008) 71.

26 Minister of State for Immigration and Ethnic Affairs $v$ Teoh (1995), 128 ALR 353, per Toohey J.

27 See e.g. In re Preston, [1985] 1 AC 835 at 851, per Lord Scarman, 864, per Lord Templeman; ex parte Coughlan, supra note 11 at para 71. For an early usage see Sir Alfred Denning, Freedom under the Law (London: Stevens \& Sons, 1949) at 99-126.

$28 R$ (Nadarajah) $v$ Secretary of State for the Home Department, [2005] EWCA Civ 1363 at para 67.

29 See e.g. Jack Beatson, "The Scope of Judicial Review for Error of Law” (1984) 4:1 Oxford J Legal Stud 22 at 22.

30 See e.g. Sir John Laws, "Law and Democracy" [1995] Pub L 72. For debate on whether it is necessary to reconcile judicial creativity with the sovereignty of parliament and, if so, how to reconcile the two, see Forsyth, supra note 15.

31 Council of Civil Service, supra note 7 at 410. 
is directed at the legality, reasonableness, and fairness of the procedures employed and actions taken by government decision makers". 32

Butterms such as "legality", "rationality"/"reasonableness" and" procedural impropriety"/"fairness" are not much more helpful than "abuse of power" in understanding the limits judges may place on administrative action: "though the general standards of legality, rationality, and procedural fairness may be firmly based in common law doctrine, their application to the facts of any particular case - and hence their concrete meaning - is largely dependent on the specific context under review". 33 What is important is to be able to translate abstract, high-level mission statements into "hard clear law". 34 Precisely what is required by way of doctrinal precision is a controversial question, ${ }^{35}$ but at the very least the mission statement must be parsed into usable doctrinal tools. For instance, legality breaks down into various subrequirements: decision-makers must interpret the law appropriately; 36 they must take into account relevant factors; they must use powers for proper purposes; and so on. ${ }^{37}$ No doubt judicial judgement will be required at some point in determining, for instance, what is relevant or proper, but this is very different from enforcing free-standing norms of legality, reasonableness and fairness.

Of critical importance to the task of refining mission statements and deciding concrete cases is an understanding of the underlying principles of judicial review. It is thus significant that, in Dunsmuir, Justice LeBel, writing with Justice Bastarache, began not with a mission statement but with a recognition that Canadian judicial review doctrine is born of an "underlying tension" between two competing principles: "Courts, while exercising their constitutional functions of judicial review, must be sensitive not only to the need to uphold the rule of law, but also to the necessity of

32 Canada (Attorney General) v TeleZone Inc., 2010 SCC 62 at para 24, [2010] 3 SCR 585.

33 TRS Allan, "Doctrine and Theory in Administrative Law: An Elusive Quest for the Limits of Jurisdiction" [2003] Pub L 429 at 431.

$34 R v$ Department of Education and Employment, ex parte Begbie, [2000] 1 WLR 1115 at para 77, per Laws LJ.

35 See e.g. Mark Elliott, "From Bifurcation to Calibration: Twin-Track Deference and the Culture of Justification" in Hanna Wilberg \& Mark Elliott, eds, The Scope and Intensity of Substantive Review: Traversing Taggart's Rainbow (Oxford: Hart Publishing, 2015) 61.

36 I say "appropriately" rather than "correctly" because in some jurisdictions the boundaries of error of law are supplied by reasonableness rather than the terms of the statute as interpreted by a court.

37 Rationality and reasonableness too require further analysis, as I explain in Part 3 of this paper. Fairness also has sub-requirements relating to the conduct of a hearing; rules of impartiality; and guarantees of independence, to be discussed in Part 4. 
avoiding undue interference with the discharge of administrative functions in respect of the matters delegated to administrative bodies by Parliament and legislatures". ${ }^{38}$ These principles have much greater capacity to shape administrative law doctrine and influence judicial review practice than have abstract references to legality and rationality. 39 Of course, these principles too must be implemented by more precise doctrinal rules, for "unless we commit to that sort of mapping project the law will continue to be rather chaotic, unprincipled, and result-orientated"; 40 if first-order normative principles are given "immediate normative operation", judges risk distributing palm-tree justice. ${ }^{41}$ Without more, legality, rationality and fairness give little guidance to jurists tasked with shaping and applying administrative law.

In short, mission statements serve the limited purpose of providing a high-level overview of the function of judicial review of administrative action in a given legal system, but they provide little detail on its operation in practice. For that, one must take a much closer look.

\section{Always Read the Label Carefully}

Sometimes, in order to take the necessary much closer look, it is necessary to carefully peel off the labels applied to particular 'forms' of administrative decision-making. These labels are conclusory, functioning as a rough description of the reasons in favour of or against judicial intervention but obscuring the true nature of the underlying concept.

For instance, it sometimes still matters in Canadian law whether a power is exercised quasi-judicially. ${ }^{42} \mathrm{~A}$ four-part test applies:

1. Is there anything in the language in which the function is conferred or in the general context in which it is exercised which suggests that a hearing is contemplated before a decision is reached?

38 Dunsmuir, supra note 22 at para 47.

39 See generally, Paul Daly, "The Unfortunate Triumph of Form over Substance in Canadian Administrative Law" (2012) 50:2 Osgoode Hall LJ 317.

40 Michael Taggart, "Proportionality, Deference, Wednesbury" [2008] NZLR 423 at 453. See similarly Yves-Marie Morissette, "Rétrospective et Prospective sur le Contentieux Administratif" (2008-09) 39 RDUS 1 at 42, expressing his fear of "une floraison chaotique de normes contradictoires".

41 Re Minister for Immigration and Multicultural Affairs; Ex parte Lam (2003), 195 ALR 502 at 519, per Gummow J.

42 For example, in determining the scope of operation of Ontario's Statutory Powers Procedure Act, RSO 1990, c S.22, or Quebec's Charter of Rights and Freedoms, RSQ c $\mathrm{C}-12$, which in $\mathrm{s} 23$ guarantees administrative independence. 
2. Does the decision or order directly or indirectly affect the rights and obligations of persons?

3. Is the adversary process involved?

4. Is there an obligation to apply substantive rules to many individual cases rather than, for example, the obligation to implement social and economic policy in a broad sense? ${ }^{43}$

But the test is hopelessly circular, liable to lead to "endless debate and immeasurable confusion". ${ }^{44}$ It is merely a description of processes that historically have been considered "quasi-judicial". It does nothing to say whether a particular, more rigorous, process should be followed in an individual case. An Irish author offers an uncannily similar verdict on the test for identifying "judicial" functions in his jurisdiction: "this definition provided only a descriptive summary...[and]...did not offer a suitably prescriptive analysis of the core concepts of the judicial function ... [I]t owes more to historical happenstance than conceptual coherence". ${ }^{45}$

Another example is provided by "legislative" decisions to which no duty of procedural fairness applies. ${ }^{46}$ The label, however, is not selfapplying. As Estey J tellingly put it, refusing to apply procedural safeguards to a "legislative" decision in Attorney General of Canada $v$ Inuit Tapirisat, "[i]t is always a question of construing the statutory scheme as a whole in order to see to what degree, if any, the legislator intended the principle [of procedural fairness] to apply". 47 There, consumers involved in a telecommunications rate-setting process appealed the resultant decision to the federal cabinet. Cabinet affirmed the decision, but accorded no participatory rights to the consumers. Although Estey J described the ratesetting decision as "legislative action in its purest form", 48 closer analysis reveals that the "legislative" label obscures the normative heavy lifting performed by a careful contextual analysis. This was a unique procedure where "the executive branch has been assigned a function performable in the past by the Legislature itself". 49 Because of the lack of "practicality"

43 Minister of National Revenue v Coopers and Lybrand, [1979] 1 SCR 495 at 504.

44 John Willis, "Section 96 of the British North America Act" (1940) 18 Can B Rev 517 at 536.

45 Eoin Carolan, "Separation of Powers and Administrative Governance" in Oran Doyle \& Eoin Carolan, eds, The Irish Constitution: Governance and Values (Dublin: Thomson Round hall, 2008) 195 at 220.

46 See e.g. Bates $v$ Lord Hailsham of St Marylebone, [1972] 3 All ER 1019 at 1024.

$47 \quad$ [1980] 2 SCR 735 at 755.

48 Ibid at 754.

49 Ibid at 758. 
of hearing all parties, ${ }^{50}$ the absence of "standards or guidelines in the exercise of its rate review function" set out in legislation 51 and the fact that the members of cabinet were asked "to respond to the political, economic and social concerns of the moment" $" 52$, according procedural rights would have been inappropriate. ${ }^{53}$ One can argue about the wisdom of Estey J's conclusion, but once the "legislative" label is removed, it is clear that the case turned on the normative considerations canvassed in his contextual analysis. ${ }^{54}$

The same can be said of another category of decision that is excluded from procedural fairness protections, that of "commercial" decisions. The leading Canadian case is Irving Shipbuilding Inc v Canada (Attorney General). ${ }^{55}$ Here, sub-contractors to an unsuccessful bidder on a government contract sought to impugn the fairness of the procedures employed. Evans JA observed that the context was "essentially commercial" and that "it will normally be inappropriate to import into a predominantly commercial relationship, governed by contract, a public law duty developed in the context of the performance of governmental functions pursuant to powers derived solely from statute". [emphasis added] ${ }^{56}$ Addition of the qualifier "normally" indicates that the formal labelling of the decision as "commercial" was not determinative. Indeed, Evans JA mentioned six reasons why permitting the sub-contractor to raise a procedural fairness argument would be inappropriate. For instance, it would raise "the alarming possibility of a cascading array of potential procedural rights holders" 57 and potentially compromise "the efficiency of the tendering process". 58 Moreover, Evans JA refused to rule out the possibility of judicial review to enforce procedural fairness at the instance of a sub-contractor "where the misconduct of government officials was so egregious that the public interest in maintaining the essential integrity of the procurement process was engaged". ${ }^{59}$ Running through this close contextual analysis is an

\footnotetext{
$50 \quad$ Ibid at 754 .

51 Ibid at 753

52 Ibid at 755

53 As I have written: "There is no neat box marked "legislative decisions". Rather, "legislative" is a label applied after-the-fact, to a conclusion reached on substantive grounds that a procedural fairness claim is inappropriate in a particular case." (Paul Daly, "The Policy/Operational Distinction - a View from Administrative Law" (2015) 69 SCLR (2d) 17 at 27).

54 See also Geneviève Cartier, "Procedural Fairness in Legislative Functions: The End of Judicial Abstinence?" (2003) 53 UTLJ 217.

552009 FCA 116, [2010] 2 FCR 488 [Irving Shipbuilding].

56 Ibid at para 46.

57 Ibid at para 50.

$58 \quad$ Ibid at para 52.

59 Ibid at para 61.
} 
appreciation of the normative underpinnings of judicial review: a concern to protect the rule of law while also safeguarding the efficiency of public administration. 60

Labels invite formalistic thinking which in turn invites confusion:

Formalism is formal in that it requires judges to operate with categories and distinctions that determine results without the judges having to deploy the substantive arguments that underpin the categories and distinctions. Since those categories and distinctions must take on a life of their own in order to operate in this detached way, they are capable of determining results that contradict the very arguments for these categories and distinctions. 61

Lawyers will more clearly understand administrative law if labels such as "quasi-judicial", "legislative" and "commercial" are removed to permit focus on the underlying normative considerations.

\section{A Hard Look at the Language of Rationality}

Language can be useful in reminding judges of the limits of the judicial role. As any student of administrative law comes quickly to understand, where a power has been assigned by legislation to an administrative body, it is not for a reviewing court to substitute its judgement on the merits of the decision taken. Administrative lawyers make a fundamental distinction between judicial review - which forms part of the inherent jurisdiction of superior courts of record but is limited to an assessment of legality - and appeals - which may only be created by statute and which may permit an appellate body to interfere on the merits: 62 "the court has no jurisdiction simply to cure administrative injustice or error". ${ }^{63}$ Where judicial review requires a consideration of the merits of an administrative decision, as in situations where the rationality of the decision is under attack, judges need to be careful to respect the autonomy of the decision-maker chosen by the legislature.

Accordingly, the terminology of rationality review is designed to remind judges of their institutional role. Lord Greene MR's formulation of Wednesbury unreasonableness is a classic example: "something so

60 See further Mark Elliott, "Judicial Review's Scope, Foundations and Purposes: Joining the Dots" [2012] NZLR 75.

61 David Dyzenhaus, "Constituting the Rule of Law: Fundamental Values in Administrative Law" (2002) 27 Queen's LJ 445 at 450.

62 See generally Paul Daly, "Les appels administratifs au Canada" (2015) 93:1 R du B can 1 .

63 Attorney General of New South Wales v Quin (1990), 170 CLR 1 at 25, per Brennan J. 
absurd that no sensible person could ever dream that it lay within the powers of the authority"; 64 courts could intervene only "if a decision on a competent matter is so unreasonable that no reasonable authority could ever have come to it ...", but this would require the applicant to demonstrate something "overwhelming". ${ }^{65}$ Other colourful formulations can be found in the cases. Lord Diplock described this ground of review as requiring "a decision which is so outrageous in its defiance of logic or of accepted moral standards that no sensible person who had applied his mind to the question to be decided could have arrived at it". ${ }^{66}$ An Irish judge saw the judicial role as "considering whether the impugned decision plainly and unambiguously flies in the face of plain reason and common sense". ${ }^{67}$ These formulations are salutary reminders of the appropriate limits of judicial oversight of the administration.

Language has played a similar role over the course of recent Canadian administrative law history, since the emergence of the "patent unreasonableness' standard of review of expert administrative decisionmakers in the 1970s. As Justice LeBel observed in CUPE (2003), the definitions of 'patent unreasonableness' offered by the Supreme Court of Canada were "intended to indicate the high degree of deference inherent in this standard of review". ${ }^{68} \mathrm{He}$ offered as examples the definitions suggested by Justice Dickson - "cannot be rationally supported by the relevant legislation"69_Justice Cory_a "very strict test ... [satisfied when a decision is] ... clearly irrational, that is to say evidently not in accordance with reason"70_ and Justice Iacobucci — a defect characterized by "immediacy or obviousness"71 leading to a decision "so flawed that no amount of curial deference can justify letting it stand". 72

However, language has its limits. Justice LeBel's reasons in CUPE (2003) represent a thoughtful engagement with the limits of language in

64 Associated Provincial Picture Houses Ltd. v Wednesbury Corporation, [1948] 1 KB 223 at 229 [Wednesbury].

65 Ibid at 230.

66 Council of Civil Service, supra note 7 at 410. Strikingly, his Lordship also commented that to "eliminate confusion", the term "reasonableness" is best avoided in public law. Ibid at 409 .

67 State (Keegan) v Stardust Victims' Compensation Tribunal, [1986] IR 642 at 658.

68 CUPE (2003), supra note 21 at para 78.

69 CUPE, supra note 21 at 237.

70 Canada (Attorney General) v Public Service Alliance of Canada, [1993] 1 SCR 941 at $963-64$.

71 Canada (Director of Investigation and Research) v Southam Inc., [1997] 1 SCR 748 at para 57.

72 Law Society of New Brunswick v Ryan, 2003 SCC 20 at para 52, [2003] 1 SCR 247. 
substantive review. At the time, the Supreme Court of Canada's framework for substantive judicial review of administrative action was under attack. Commentators decried the "epistemological" confusion 73 created by an unwieldy four-factor analysis ${ }^{74}$ combined with three standards of review, a non-deferential standard of correctness that permitted a reviewing court to substitute its view for that of the decision-maker and two deferential standards: reasonableness simpliciter and patent unreasonableness.

In a memorable passage, one first-instance judge wrote:

In attempting to follow the court's distinctions between "patently unreasonable", "reasonable" and "correct", one feels at times as though one is watching a juggler juggle three transparent objects. Depending on the way the light falls, sometimes one thinks one can see the objects. Other times one cannot and, indeed, wonders whether there are really three distinct objects there at all. ${ }^{75}$

Justice LeBel began by noting that the judiciary must ensure a "predictable, workable and coherent jurisprudence" for use by lawyers, litigants and lower courts, ${ }^{76}$ a duty they had failed in because the prevailing law "does not currently provide sufficiently clear parameters". ${ }^{77}$ The limits of terminological exactitude could be most clearly observed in judicial attempts to distinguish reasonableness simpliciter from patent unreasonableness. As Justice LeBel explained, the two standards shared an underlying analytical basis - that there will be sometimes, perhaps often, be more than one possible reasonable interpretation of a statutory provision, in which case a reviewing court should defer to the wisdom of the front-line decisionmaker: "Because patent unreasonableness and reasonableness simpliciter are both rooted in this guiding principle, it has been difficult to frame the standards as analytically, rather than merely semantically, distinct". ${ }^{78}$

73 David J Mullan, "Recent Developments in Standard of Review" in Canadian Bar Association (Ontario), Taking the Tribunal to Court: A Practical Guide for Administrative Law Practitioners (October 20, 2000) at 26 [Mullan].

74 For the uninitiated: statutory language (the presence or absence of a privative clause or right of appeal); the nature of the question (legal or factual); the relative expertise of the decision-maker and the reviewing court; and the purpose of the provision at issue (policy-making choice or the application of an objective legal norm to the facts as found).

75 Miller v Workers' Compensation Commission (Nfld.) (1997), 154 Nfld \& PEIR 52 (Nfld SCTD) at para 27, per Barry J (as he then was). I note that Barry JA (as he now is) remains interested in these issues: see the excellent discussion in Workplace Health, Safety and Compensation Commission v Allen, 2014 NLCA 42, 379 DLR (4th) 271.

76 CUPE (2003), supra note 21 at para 64.

77 Ibid at para 66.

78 Ibid at para 103. 
Indeed, the gallant efforts to distinguish the indistinguishable came to resemble judicial linguistic gymnastics as judges fell over one another in their attempts to achieve a perfect verbal distillation of the two deferential standards of unreasonableness. Thus Cory J's invocation of the adjective "clearly" added little more than "rhetorical effect". ${ }^{79}$ LeBel J also cited a first-instance judge who had commented: "If the unreasonableness of a decision is not clear or obvious, I do not see how that decision can be said to be unreasonable". 80 However, as long as the judicial inquiry was into whether a decision was rationally supported by the reasoning and evidence offered by the decision-maker, a meaningful distinction "attempting to qualify degrees of irrationality" 81 would be impossible: "There seems to me to be no qualitative basis on which to differentiate effectively between these various characterizations of a rationality analysis; how, for instance, would a decision that is not "tenably supported" (and is thus "merely" unreasonable) differ from a decision that is not "rationally supported" (and is thus patently unreasonable)?" 82 The same was true of a "somewhat probing examination" 83 of a decision, difficult to distinguish from one that is "simply probing, or...less than probing"; 84 whether it was designed to identify an immediately obvious defect or one that is obvious once it has been discovered. ${ }^{85}$ And if a "merely" unreasonable decision should be allowed to stand because it was not "clearly" or "patently" unreasonable, or a defect overlooked because it required more than a "somewhat probing examination" to uncover it, the law would be according irrationality a "legitimate presence in the legal system", 86 a most unsavoury prospect. 87

In 2003, Justice LeBel saw "no easy way out of this conundrum", 88 but his preferred solution was relatively clear, as he signed off by asking "[s]hould courts move to a two standard system of judicial review, correctness and a revised unified standard of reasonableness". ${ }^{89}$ Sure enough, five years later, Justice LeBel and Justice Bastarache wrote the

79 Mullan, supra note 73 at 24.

80 Hao $v$ Canada (Minister of Citizenship and Immigration) (2000), 184 FTR 246 at para 9, per Reed J.

81 CUPE (2003), supra note 21 at para 111.

$82 \quad$ Ibid at para 107.

83 Canada (Director of Investigation and Research) v Southam Inc., [1997] 1 SCR 748 at para 56.

84 DW Elliott, "Suresh and the Common Borders of Administrative Law: Time for the Tailor?" (2002) 65 Sask L Rev 469 at 486-87, cited in CUPE (2003), supra note 21 at para 112.

85 CUPE (2003), supra note 21 at paras 116-120.

$86 \quad$ Ibid at para 132.

87 Ibid at paras 109, 125.

$88 \quad$ Ibid at para 121.

$89 \quad$ Ibid at para 134. 
set of reasons in Dunsmuir that abolished the two deferential standards and replaced them with one:

\begin{abstract}
Reasonableness is a deferential standard animated by the principle that underlies the development of the two previous standards of reasonableness: certain questions that come before administrative tribunals do not lend themselves to one specific, particular result. Instead, they may give rise to a number of possible, reasonable conclusions. Tribunals have a margin of appreciation within the range of acceptable and rational solutions. A court conducting a review for reasonableness inquires into the qualities that make a decision reasonable, referring both to the process of articulating the reasons and to outcomes. In judicial review, reasonableness is concerned mostly with the existence of justification, transparency and intelligibility within the decision-making process. But it is also concerned with whether the decision falls within a range of possible, acceptable outcomes which are defensible in respect of the facts and law. ${ }^{90}$
\end{abstract}

But this definition too has difficulties. What exactly do "justification", "transparency" and "intelligibility" mean? Just as it added little to "irrational" to add "clearly", so it added little to "reasonableness" to add these abstract hallmarks of best administrative practice. Indeed, some courts took this aspirational language as a departure from the policy of deferential self-restraint and a signal to intervene more readily in the administrative process. ${ }^{91}$ The Court soon replaced its aspirational language with a more restrictive and more precise formulation. ${ }^{92}$ As Justice LeBel put it in a subsequent case, the question is whether the reviewing court can "clearly understand" the thought process of the decision-maker.93 Even here, language alone cannot do all the work - for to apply this test a reviewing court must appreciate the role of reasons and the record in permitting it to perform its task of ensuring that the decision under review was reasonable ${ }^{94}$ - but it sets out a comprehensible criterion for judicial judgement.

$90 \quad$ Dunsmuir, supra note 22 at para 47.

91 See e.g. Driver Iron Inc. $v$ International Association of Bridge, Structural Ornamental and Reinforcing Ironworkers, Local Union No. 720 (2011), 502 AR 229 (CA), rev'd 2012 SCC 65, [2012] 3 SCR 405; Public Service Alliance of Canada v Canada Post Corporation, [2011] 2 FCR 221 (CA), rev'd 2011 SCC 57, [2011] 3 SCR 572.

92 Newfoundland and Labrador Nurses' Union v Newfoundland and Labrador (Treasury Board), 2011 SCC 62 at para 14, [2011] 3 SCR 708: "the reasons must be read together with the outcome and serve the purpose of showing whether the result falls within a range of possible outcomes".

93 Agraira v Canada (Public Safety and Emergency Preparedness), 2013 SCC 36 at para 89, [2013] 2 SCR 559.

94 See e.g. Leahy $v$ Canada (Citizenship and Immigration), 2012 FCA 227 at para 122, [2014] 1 FCR 766: "Any reviewing court upholding a decision whose bases cannot be discerned would blindly accept the decision, abdicating its responsibility to ensure that it is 
Being misled by linguistic formulations is not a pitfall unique to the Canadian legal landscape. The United States has its 'hard look' test for determining whether an administrative decision was arbitrary or capricious. Does this mean that reviewing courts must literally take a hard look at the material in the record, reading it twice or three times, or perhaps with the aid of a magnifying glass? But shouldn't they always take a hard look?95 Similar questions might be posed of England's 'anxious scrutiny' standard: shouldn't a judge's scrutiny always be anxious? Is 'anxious scrutiny' to be juxtaposed against 'relaxed scrutiny', performed perhaps under the influence of barbiturates? The answer is no. Indeed, the 'hard look' and 'anxious scrutiny' labels are dangerously misleading. Arbitrary and capricious review is in fact similar to-perhaps indistinguishable fromthe grounds of abuse of discretion well known to the common law; ${ }^{96}$ and anxious scrutiny imposes additional process obligations on decision-makers in sensitive cases..$^{97}$ In neither case does the language of hardness or anxiety do any analytical work.

The difficulty in all of these cases lies in using descriptive language as a substitute for doctrinal precision. As Lord Greene MR observed in Wednesbury, reasonableness "has frequently been used and is frequently used as a general description of the things that must not be done". 98 Yet what really matters is whether judicial intervention is justifiable. This is purely a normative question. ${ }^{99}$ Thinking that descriptive language can provide the necessary normative basis for judicial intervention (or, indeed, judicial restraint) is a serious error. A judge must demonstrate why there is a basis for intervention, something that requires engagement with the

consistent with the rule of law". See also Wall v Office of the Independent Police Review Director, 2014 ONCA 884.

95 In practice the look might not be very hard at all. See Jacob E Gersen \& Adrian Vermeule, "Thin Rationality Review" (2016) 114:8 Mich L Rev 1355.

96 Motor Vehicle Manufacturers Association v State Farm Mutual Automobile Insurance, 463 US 29 at 43 (1983):

Normally, an agency rule would be arbitrary and capricious if the agency has relied on factors which Congress has not intended it to consider, entirely failed to consider an important aspect of the problem, offered an explanation for its decision that runs counter to the evidence before the agency, or is so implausible that it could not be ascribed to a difference in view or the product of agency expertise.

97 Paul Craig, "Judicial Review and Anxious Scrutiny: Foundations, Evolution and Application" [2015] Pub L 60.

98 Wednesbury, supra note 64 at 229.

99 See e.g. Delios v Canada (Attorney General), 2015 FCA 117 at para 26:

Bearing in mind the margin of appreciation that the administrator should be given - a margin that can be narrow, moderate or wide according to the circumstances - we examine the administrator's decision in light of the evidentiary record and the law, to examine whether the decision is acceptable and defensible on the facts and the law. 
underlying "substantive principles" 100 or "reason and structure"101 of unreasonableness or irrationality. 102 Otherwise, the reviewing court risks overstepping the limits of the judicial role by substituting judgement on the merits of the question at issue; at the very least, it "renders doctrinal analysis otiose". 103 Ultimately, the result of such "verbal gymnastics"104 is "a terminological overload [that] can only result in distracting formalism and obfuscation of administrative law principles". ${ }^{105}$

Sometimes the error of substituting descriptive terms for normative analysis is compounded by the introduction of a hypothetical reasonable observer. Consider these observations of an Irish judge:

$[\mathrm{T}]$ he kind of error that produces invalidity is one which no rational or sane decision maker, no matter how misguided could essay to be reviewably irrational. It is not sufficient that a decision maker goes wrong or even hopelessly or fundamentally wrong: he must have gone completely and inexplicably mad: taken leave of his senses and come to an absurd conclusion. It is only when this last situation arises or something akin to it that a court will review the decision for irrationality. ${ }^{106}$

Not only does this passage reveal the standard error of those who search in vain for terminological exactitude-what is the difference between the "wrong" and the "hopelessly or fundamentally wrong"? - but it also conjures up a mythical decision-maker who has been afflicted by madness, as if the judge's role were to imagine himself as a delirious official asked to take an administrative decision. But judicial review does not require such leaps of imagination. It requires only that judges ask whether a decision should stand or fall and apply appropriate criteria in answering this question.

100 Anthony Lester \& Jeffrey Jowell, "Beyond Wednesbury: Substantive Principles of Administrative Law" [1987] Pub L 368.

101 Paul Daly, “Wednesbury's Reason and Structure” [2011] Pub L 237.

102 See also Paul Craig, "The Nature of Reasonableness Review" [2013] Current Legal Prob 1, though for all that Craig is persuasive in demonstrating that reasonableness review requires consideration by judges of the weight given to relevant factors by decisionmakers, he does not provide much guidance to judges charged with assessing reasonableness in a particular case because his preference is for the introduction of a context-sensitive proportionality test.

103 William Wade \& Christopher Forsyth, Administrative Law, 11th ed (Oxford: Oxford University Press, 2014) at 304, fn 124.

104 Stanley Alexander de Smith, Judicial Review of Administrative Action, 1st ed (London: Stevens \& Sons, 1959) at 50.

105 Philip A Joseph, Constitutional and Administrative Law in New Zealand, 4th ed (Wellington: Brookers, 2014) at 900.

106 Aer Rianta v Commissioner for Aviation Regulation, High Court of Ireland, January 16, 2003, O’Sullivan J, unreported. 


\section{The Fabulous Baker Factors and the Spectrum of Procedural Fairness}

One very useful way to conceptualize the administrative state is to perceive it as a spectrum, ${ }^{107}$ along which, as Justice LeBel put it in Imperial Oil, the requirements of the law "may vary in order to reflect the context of a decision-maker's activities and the nature of its functions": 108

The categories of administrative bodies involved range from administrative tribunals whose adjudicative functions are very similar to those of the courts, such as grievance arbitrators in labour law, to bodies that perform multiple tasks and whose adjudicative functions are merely one aspect of broad duties and powers that sometimes include regulation-making power. The notion of administrative decision-maker also includes administrative managers such as ministers or officials who perform policy-making discretionary functions within the apparatus of government. 109

This well-known idea of a "spectrum"110 can be roughly mapped as follows: Ministers ${ }^{111} \rightarrow$ Crown Corporations ${ }^{112} \rightarrow$ Social and Economic Regulators $^{113} \rightarrow$ Quasi-Judicial Functions ${ }^{114} \rightarrow$ Judicial Functions. ${ }^{115}$

107 On the general range of administrative decision-makers, the discussion in Gilles Pépin, Les tribunaux administratifs et la Constitution : Étude des articles 96 à 101 de l'A.A.N.B. (Montréal : Presses de l'Université de Montréal, 1969) at 48-69 remains instructive.

108 Imperial Oil, supra note 23 at para 31.

109 Ibid.

110 Martineau v Matsqui Disciplinary Board, [1980] 1 SCR 602 at 628-29, per Dickson J, dissenting:

A purely ministerial decision, on broad grounds of public policy, will typically afford the individual no procedural protection, and any attack upon such a decision will have to be founded upon abuse of discretion. Similarly, public bodies exercising legislative functions may not be amenable to judicial supervision. On the other hand, a function that approaches the judicial end of the spectrum will entail substantial procedural safeguards. Between the judicial decisions and those which are discretionary and policy-oriented will be found a myriad decision-making processes with a flexible gradation of procedural fairness through the administrative spectrum.

See also Apotex Inc. v Canada (Attorney General), [2000] 4 FCR 264 at para 104, per Evans JA, referring to "the spectrum of powers ranging from the legislative, through the administrative, to the judicial".

111 I have in mind here government departments headed by a politician who is accountable to a legislature (and perhaps also, as a modern addition to the convention of responsible government, to the public at large) and in whose name departmental officials may act.

112 I have in mind here the various bodies established by the state to achieve commercial goals; these are relatively rarely subject to judicial review because their activities are primarily commercial in nature, but they are subject to governmental control. 
Viewing functions on this spectrum is a very useful, intuitive way of grasping many of the issues that arise in terms of political and legal control of the administration. ${ }^{116}$ On the purely political end of the spectrum lies ministerial decision-making, where political control through conventions of accountability to the legislature predominates. Here, procedural protections are diminished - indeed, in Imperial Oil, an argument that the minister was biased because his department would have won a budgetary windfall from penalizing an oil company failed for precisely this reason. In addition, the range of considerations that a minister might take into account in making a decision is often very broad indeed. ${ }^{117}$

On the purely legal end of the spectrum lies judicial decision-making. By "judicial" in this context, I do not mean decision-making by courts of law. Rather, I am concerned with the application by administrative bodies of objective legal norms to the facts as found. The French term "juridictionnelle", which does not have a ready English equivalent, captures the idea. Here, political interference is - or at least should be 118 - frowned upon, for the distribution of costs and benefits set out by the legislature should not be interfered with by executive fiat. ${ }^{119}$ Legal control is heightened, in

113 I have in mind here bodies charged with regulating complex aspects of society and the economy. Central banks, telecommunications regulators and competition regulators would fall under this rubric.

114 I have in mind here administrative tribunals that the legislature has established to settle disputes, usually between an administrative body and an individual but sometimes (as with human rights tribunals) between two individuals. Often these tribunals complement the work of social and economic regulators: in some of its functions, for instance, a telecommunications regulator will act quasi-judicially but in others it will act as a developer of general rules of policy for its sector.

115 I explain this term further below: the difference between a quasi-judicial and judicial function is simply one of degree, with a quasi-judicial decision-maker entitled to take into account a broader range of factors - such as the overall effect of a decision on achievement of its policy goals - than a judicial decision-maker.

116 For this distinction, see e.g. Adam Tomkins, Our Republican Constitution (Oxford: Hart Publishing, 2005).

117 See e.g. Canada (Minister of Transport, Infrastructure and Communities) v Jagjit Singh Farwaha, 2014 FCA 56 at paras 88-99.

118 Ron Ellis, Unjust by Design: Canada's Administrative Justice System (Vancouver: UBC Press, 2013) [Ellis] inveighs most effectively against political interference, largely unremarked by the wider public, with judicial tribunals.

119 Martin Shapiro, Who Guards the Guardians? Judicial Control of Administration (Athens: University of Georgia Press, 1988) at 112:

Imagine our outrage if, at the end of a court trial, the president of the United States called up the judge and told her how he wanted the case to come out. Let us suppose an agency has held a rule-making proceeding that involved hundreds of hours of testimony and thousands of pages of written submissions. It has listened at length to every interested group and heard the rebuttal of each group to the testimony of 
the sense that the range of considerations that a judicial decision-maker may legitimately take into account is tightly constrained: if the question is whether an applicant has accumulated enough days of work to claim an entitlement, the decision-maker cannot rove into the applicant's conduct or utility to society. Procedural protections are at their strongest here, where the decision-making process - the application of objective legal norms 120 to facts - closely resembles that of a court of law.

In between the two extremes, the extent of political and legal control varies as one moves back and forth along the spectrum, more strongly legal towards the judicial end, more strongly political towards the ministerial end. In terms of giving a snapshot of the administrative state and providing a rough idea against which one's intuitions about the appropriate level of political and legal control can be tested, this spectrum of functions is exceedingly useful.

Yet lawyers would do well to heed Cardozo's warning: "Metaphors in law are to be narrowly watched, for starting as devices to liberate thought, they end often by enslaving it". ${ }^{121}$ As useful as it is, the metaphor of the spectrum may serve to distract courts from their role in ensuring procedural fairness in the administrative process. In procedural fairness cases, decisions are often said to turn on an appreciation of all the relevant context: "Like the principles of natural justice, the concept of procedural fairness is eminently variable and its content is to be decided in the specific context of each case". ${ }^{122}$ An administrative process "need not assume the trappings of a

every other. It has compiled a thousand-page-long rule-making record. It has then composed a statement showing that it has acted synoptically to consider every significant issue and arrive at the best possible decision. Those who have been watching and participating in such a process are going to be equally outraged if, just before the agency publishes its final rule, the president calls to tell the agency what rule it should adopt.

120 An intelligent student once objected to me that not all norms applied by courts of law can truly be described as objective, open-textured constitutional provisions being perhaps the best example. This is a complicated area (see e.g. Matthew H Kramer, Objectivity and the Rule of Law (Cambridge: Cambridge University Press, 2007); $R$ v Department of Education and Employment, ex parte Begbie, [2000] 1 WLR 1115 at para 78, per Laws LJ ("Fairness and reasonableness (and their contraries) are objective concepts; otherwise there would be no public law, or if there were it would be palm tree justice")). I nonetheless think the basic point about the application of law to facts withstands scrutiny.

121 Berkey v Third Avenue Railway Company, 244 NY 84 at 94 (1926). This is not to deny that metaphors might have cognitive effects (James E Murray, "Understanding Law as Metaphor" (1984) 34 JL Educ 714), but rather to suggest that these are often malign, at least in administrative law.

122 Knight v Indian Head School Division No. 19, [1990] 1 SCR 653 at 682. 
court". 123 Only "some kind of hearing"124 in which the conventional list of procedural protections - notice, making submissions, representation by counsel, cross-examination of witnesses and so on - need not be followed to the letter. Depending on the interplay of the five "Baker" factors, ${ }^{125}$ a particular decision can be placed on the spectrum somewhere between the two extremes in order to determine the appropriate procedural protections:

\begin{abstract}
Some administrative tribunals are closer to the executive end of the spectrum: their primary purpose is to develop, or supervise the implementation of, particular government policies. Such tribunals may require little by way of procedural protections. Other tribunals, however, are closer to the judicial end of the spectrum: their primary purpose is to adjudicate disputes through some form of hearing. Tribunals at this end of the spectrum may possess court-like powers and procedures. [emphasis added] $^{126}$
\end{abstract}

However, the use of "may" in this passage is telling. Placing a decision on a spectrum is not enough. Something more is required before a court can satisfy itself that the procedure at issue was fair or unfair. Indeed, the metaphor of the spectrum obscures more than it reveals. The Baker factors emphasize the importance of context and evoke a spectrum of administrative functions but they do not assist courts or decision-makers in determining whether a particular procedural right should be granted in a particular case. In reality, very specific normative criteria attach to each of the procedural rights that an individual may claim in the administrative process. For example: minimum standards of fairness require that an individual "have full and complete notice of the charges against him and an opportunity to

\title{
123 Ibid at para 49.
}

124 Henry J Friendly, "Some Kind of Hearing” (1975) 123 U Pa L Rev 1267.

125 Baker, supra note 12. This non-exhaustive list (ibid at para 28) was summarized more recently in Canada (Attorney General) v Mavi, 2011 SCC 30 at para 42, [2011] 2 SCR 504:

(i) "the nature of the decision being made and the process followed in making it" (para. 23); (ii) "the nature of the statutory scheme and the "terms of the statute pursuant to which the body operates"" (para. 24); (iii) "the importance of the decision to the individual or individuals affected" (para. 25); (iv) "the legitimate expectations of the person challenging the decision" (para. 26); and (v) "the choices of procedure made by the agency itself, particularly when the statute leaves to the decision-maker the ability to choose its own procedures, or when the agency has an expertise in determining what procedures are appropriate in the circumstances" (para. 27).

The citations are to Baker.

126 Bell Canada v Canadian Telephone Employees Association, 2003 SCC 36 at para 2, [2003] 1 SCR 884. See further Colleen Flood \& Lorne Sossin, "The Contextual Turn: Iacobucci's Legacy and the Standard of Review in Administrative Law" (2007) 57:2 UTLJ 581. 
reply thereto"; 127 an oral hearing will be required where it is necessary to determine an issue of credibility; 128 evidence cannot be refused on a critical point; ${ }^{129}$ representation by counsel is required only where the proceedings are so important and complex that an individual will be unable to make his or her case effectively; 130 and cross-examination need only be permitted where it is necessary to ensure the decision-maker has the "full story". ${ }^{131}$ In this sense, the Baker factors are fabulous. Some judicial judgement will be required in determining the answers to the more specific questions relating to particular procedural rights, but judges are certainly not roving along a spectrum in search of a mirror image of the type of process presented by the case in hand.

A risk of swallowing bromides about context and relying on the vague, abstract notion of a spectrum to 'resolve' concrete cases is that courts may create "a modern version of Sir William Wade's nightmare of a Tennysonian 'wilderness of single instances' in which all the contextual factors will be relevant in considering what the requirements of procedural fairness are in a given situation without any factor or group of factors having decisive weight in shaping what is in practice required". ${ }^{132}$ However, jurists can avoid this danger by understanding that the question in procedural fairness cases is whether a particular right should have been accorded - not whether the procedure was in fact consistent with the decision-maker's place on the spectrum of administrative procedures. Fairness is a normative matter, not a descriptive one.

The metaphor of the spectrum also causes problems in determining the appropriate degree of administrative independence from outside interference. Take, for instance, a central bank whose mandate is to set monetary policy. On the spectrum of procedural fairness, a central bank would fall more or less in the middle, along with telecommunications and competition regulators and similar bodies. Yet central bank independence from political interference is a cherished norm of most developed liberal democracies. ${ }^{133}$ For instance, even though the Bank of Canada is formally

127 Confederation Broadcasting (Ottawa) Ltd. v Canadian Radio-Television Commission, [1971] SCR 906 at 925.

128 Khan $v$ University of Ottawa (1997), 34 OR (3d) 535.

129 Université du Québec à Trois-Rivières v Larocque, [1993] 1 SCR 471.

130 New Brunswick (Minister of Health and Community Services) v G. (J.), [1999] 3 SCR 46 at para 86 .

131 Irvine v Canada (Restrictive Trade Practices Commission), [1987] 1 SCR 181 at para 87.

132 R. (L.) v West London Mental Health NHS Trust, [2014] EWCA Civ 47 at para 72, (per Beatson LJ).

133 Adrian Vermeule, "Conventions of Agency Independence" (2013) 113 Colum L Rev 1163. 
subject to the authority of the Minister of Finance, with whom its governor must meet regularly, ${ }^{134}$ howls of outrage greet any perceived political interference with the establishment of monetary policy. ${ }^{135}$ Howls of outrage that, one might add, are often absent when politicians attempt to influence judicial decision-making by administrative tribunals. Clearly the metaphor of the spectrum fails to capture important information about administrative independence from political interference.

Moreover, the idea of a set of administrative functions that may glide along a spectrum militates against any suggestion that some decisionmakers should be given special protection. Ellis has convincingly argued, for instance, that administrative tribunals exercising judicial functions should be protected by the same doctrines of independence that courts of law benefit from: norms that guarantee security of tenure, security of remuneration and institutional autonomy. ${ }^{136}$ Indeed, in the province of Quebec, where administrative independence has a quasi-constitutional status, courts have been able to ensure these protections for administrative tribunals. It might be the case that the metaphor of the spectrum has such a hold on the judicial imagination that it has become impossible to conceive of an administrative tribunal with a dedicated, single function that is so important as to warrant heightened protection. A metaphor that evokes movement may shield from the judicial eye the need for special protection at certain fixed points on the spectrum. ${ }^{137}$

134 Bank of Canada Act, RSC 1985, c B-2, s 14.

135 See e.g. Andrew Coyne, "Bank of Canada, a.k.a the Harper government, needs to be honest about its monetary policy", National Post (January 22, 2014), online: <www. nationalpost.com/>.

136 Ellis, supra note 118.

137 This is not to say that administrative tribunals exercising judicial functions should be treated as the functional equivalents of courts of law. In the rigorous enforcement of norms of independence, context may legitimately be taken into account: the Quebec Court of Appeal has been very clear about the importance of following a nuanced approach that is attentive to context. See e.g. Association des juges administratifs de la Commission des lésions professionnelles c Québec (Procureur général), 2013 QCCA 1690, where the Court of Appeal refused to require that members of the Commission des lésions professionnelles be treated identically to members of the Tribunal administratif du Québec in terms of independence. As Bich JA explained at para 27:

Les garanties conférées en cette matière aux tribunaux administratifs, et qui trouvent leur source dans les règles de la justice naturelle, peuvent donc varier et elles varieront en fonction de la nature précise du pouvoir décisionnel et des modalités d'exercice de ce pouvoir, le tout sous réserve des termes de la loi. Dans cet ordre fluctuant, le tribunal administratif qui exerce des fonctions purement juridictionnelles - et la Cour suprême, là encore, l'a confirmé- doit offrir le niveau de garantie le plus élevé, niveau qui n'a cependant pas, je me permets de le répéter, à être celui des cours supérieures ni même celui des autres cours de justice. 


\section{The Problematic Personification of the Reasonable Observer}

As is well known, "it is not merely of some importance but is of fundamental importance that justice should not only be done, but should manifestly and undoubtedly be seen to be done". 138 All public bodies are subject to this rule against bias, though it is applied flexibly to administrative decisionmakers. ${ }^{139}$ In administrative law, the question is always "what would an informed person, viewing the matter realistically and practically-and having thought the matter through-conclude. Would he think that it is more likely than not that [the decision-maker] whether consciously or unconsciously, would not decide fairly?"140

Unfortunately, the suggestion that the so-called 'reasonable observer' might actually be a real person is a source of intractable difficulty in this area. ${ }^{141}$ This 'reasonable observer' is purely a judicial construct; indeed, in attributing various degrees of knowledge to the hypothetical observer, a judge may simply be "holding up a mirror to himself". ${ }^{142}$ Although it is more accurate to say that "the court in cases such as these personifies the reasonable man", ${ }^{143}$ any reference to a hypothetical reasonable person "encourages the conflation of 'descriptive' attributes of the person with the normative standard of behaviour". 144 This is an invitation to woolly thinking: decisions justified on the basis that 'a reasonable person would think X' with little or no discussion of why the judge believes intervention would be appropriate or inappropriate.

A court faced with an allegation of biased decision-maker should not ask: "Would the hypothetical reasonable person think the decision-making was not impartial?" Rather, the question should be: "Should the decisionmaker recuse herself?" Or, as the High Court of Australia would have

$138 R v$ Sussex Justices, Ex parte McCarthy, [1924] 1 KB 256 at 259, per Lord Hewart CJ.

139 See e.g. Russell v Duke of Norfolk, [1949] 1 All ER 109 at 118, per Tucker LJ:

There are, in my view, no words which are of universal application to every kind of inquiry and every kind of domestic tribunal. The requirements of natural justice must depend on the circumstances of the case, the nature of the inquiry, the rules under which the tribunal is acting, the subject-matter that is being dealt with, and so forth.

140 Committee for Justice and Liberty et al. v National Energy Board et al., [1978] 1SCR 369 at 394, per De Grandpré J, dissenting, quoting the judgment under appeal: [1976] 2 FC 20.

141 Abimbola A Olowofoyeku, "Bias and the Informed Observer: A Call for a Return to Gough" (2009) 68:2 CLJ 388.

142 Lord Rodger of Earlsferry, Bias and Conflicts of Interest: Challenges for Today's Decision-Makers, 24th Sultan Azlan Shaw Lecture, 2010, 435 at 467.

$143 R v$ Gough, [1993] AC 646 at 668, per Lord Goff.

144 Mayo Moran, Rethinking the Reasonable Person: An Egalitarian Reconstruction of the Objective Standard (Oxford: Oxford University Press, 2003) at 9. 
it, "There must be an articulation of the logical connection between the matter and the feared deviation from the course of deciding the case on its merits". ${ }^{145}$ Abandoning the pretense that hypothetical reasonable persons have any role to play in administrative law adjudication is a necessary precondition to a meaningful inquiry that will enable jurists to determine when reviewing courts should intervene on the grounds of partiality. ${ }^{146}$

When it comes to questions of bias, unfortunately, clear rules are elusive. There are no equivalents to the procedural fairness rules that are obscured by the metaphor of the spectrum-perhaps for this reason the hypothetical reasonable observer continues to persist. The inquiry is always "highly fact-specific": "There are no shortcuts". ${ }^{147}$ A significant pecuniary interest, ${ }^{148}$ prejudicial comments before or during a decision-making process, ${ }^{149}$ a prior relationship with one of the parties, ${ }^{150}$ pre-judgement of the issues, ${ }^{151}$ or overly vigorous prosecution ${ }^{152}$ can make a decisionmaker's position untenable. But the relevant question is not what a man or woman plucked off the street at random would say about the impartiality of the decision-maker: what matters is the judge's considered view of the decision-maker's ability to conduct a fair hearing. As Gageler J recently put it, in an Australian case in which a prosecutor had also participated in the adjudication of the proceedings she had earlier been involved in, "a person who has been the adversary of another person in the same or related proceedings can ordinarily be expected to have developed in that role a frame of mind which is incompatible with the exercise of that degree of neutrality required dispassionately to weigh legal, factual and policy considerations relevant to the making of a decision which has the potential adversely to affect interests of that other person". [emphasis added] ${ }^{153}$ This conclusion adequately captures the normative content of the requirement of administrative impartiality.

One area of the rule against bias in which courts have achieved an important degree of clarity is that relating to decisions taken by elected officials. When a representative of a segment of the population is exercising

145 Ebner v Official Trustee in Bankruptcy (2000), 205 CLR 337 at 345.

146 Laverne Jacobs, "From Rawls to Habermas: Toward a Theory of Grounded Impartiality in Canadian Administrative Law" (2014) 51:2 Osgoode Hall LJ 543.

147 Wewaykum Indian Band v Canada, 2003 SCC 45, [2003] 2 SCR 259 at para 77 [Wewaykum].

148 Pearlman v Manitoba Law Society Judicial Committee, [1991] 2 SCR 869.

149 Newfoundland Telephone Co. $v$ Newfoundland (Board of Commissioners of Public Utilities), [1992] 1 SCR 623 [Newfoundland Telephone].

150 Wewaykum, supra note 147.

151 Beaverford $v$ Thorhild (County No. 7), 2013 ABCA 6.

152 College of Physicians \& Surgeons (Ontario) v Casullo, [1977] 2 SCR 2.

153 Isbester v Knox City Council, [2015] HCA 20 at para 63. 
a non-adjudicative function, ${ }^{154}$ she may speak freely of her intuitions about future decisions as long as she does not demonstrate a closed mind. ${ }^{155}$ Here at least the rule is clear. Of course it is not self-applying and cannot be enforced without a modicum of subjective judicial judgement, but the achievement of clarity suggests that once the defective tool of personification is cast aside, sustained reflection on the normative underpinnings of the rule against bias may yield rewarding outcomes.

\section{Conclusion}

My argument has been that the use of descriptive language - in many different guises - obscures the fundamentally normative task of judicial review of administrative action. The ills described here are not at all unique to administrative law, 156 but they have caused significant malaise in the subject. High-level descriptions may occasionally be useful in furthering understanding or facilitating dialogue across national boundaries. But care is required. Descriptive language is often either useless - because it adds nothing but a conclusory label to a conclusion reached on other groundsor downright dangerous - because it hides the norms guiding judges - or both. It should be discarded where possible. Administrative lawyers have to think and judges to justify themselves in normative terms. Mission statements, labels, terminological exactitude, metaphors and personification are descriptive devices better left to others.

154 Newfoundland Telephone, supra note 149.

155 Old St. Boniface Residents Assn Inc v Winnipeg (City), [1990] 3 SCR 1170. For an earlier authority, using slightly different concepts, see Franklin v Minister of Town and Country Planning, [1948] AC 87.

156 See e.g. JC Smith, "The Limits of Tort Liability in Canada: Remoteness, Foreseeability and Proximate Cause" in Allen M Linden, ed, Studies in Canadian Tort Law (Toronto: Butterworths, 1968) at 88. 